\title{
PENGARUH HERBAFARM DAN PUPUK NPK MUTIARA 16:16:16 TERHADAP PERTUMBUHAN DAN PRODUKSI TANAMAN KACANG HIJAU (Vignaradiata L.)
}

\section{Effect of Herbafarm and NPK Pearl 16:16:16 Fertilizer on Growth and Production of Mung Bean Plants (Vigna radiata L.)}

\author{
Rahmayani Pulungan, Maizar, M. Nur \\ Program Studi Agroteknologi, Fakultas Pertanian Universitas Islam Riau \\ Jl. Khaharuddin Nasution No.113 Pekanbaru. 28284 \\ Telp: 0761-674681; Fax: 0761-674681 \\ [Diterima: Juli 2018; Disetujui: Agustus 2018]
}

\begin{abstract}
The purpose of this study was to determine the interaction and main effects of herbafarm and NPK Mutiara 16:16:16 fertilizer on the growth and production of mung bean plants. $(\mathrm{H})$ consisting of 4 levels namely $0,1.5,3,4.5 \mathrm{cc} / \mathrm{L}$ of water, and the second factor is NPK Mutiara 16:16:16 (N) consisting of 4 levels of treatment namely $0,10.8,21.6,32.4$ grams/plot, so that there are 16 treatment combinations with 3 replications there are 48 experimental unit plots. Each experimental unit consisted of 12 plants and 2 of them were used as sample plants so that the entire plant was 576 plants. The best treatment was giving herbafarm $3 \mathrm{cc} / 1$ water and NPK fertilizer pearl $21.6 \mathrm{~g} /$ plot $((\mathrm{H} 2 \mathrm{~N} 2)$ with the results the best filling speed of dry matter is $0.33 \mathrm{~g}$, the percentage of planted pods is $71.33 \%$, the weight of dry seeds is 27.50 grams per harvest. The main effect of giving herbafarm 3 $\mathrm{cc} / 1$ water gives the best results on plant height $65.67 \mathrm{~cm}$, age flowering 31.92 days, effective filling time 19.74 days and weighing 100 seeds 5.99 grams, while applying NPK pearl fertilizer $21.6 \mathrm{~g} / \mathrm{plot}$ gives the best results on plant height $61.67 \mathrm{~cm}$ and effective filling time 19.90 days, but the application of pearl NPK fertilizer $32.4 \mathrm{~g} /$ plot gave the best results at the age of flowering 32.26 days and weighing 100 seeds 5.96 grams.
\end{abstract}

Keywords: Herbafarm, Growth, Production, Mung Beans.

\begin{abstract}
ABSTRAK
Tujuan penelitian ini adalah untuk mengetahui pengaruh secara interaksi dan utama herbafarm serta pupuk NPK Mutiara 16:16:16 Terhadap Pertumbuhan dan Produksi Tanaman Kacang Hijau.Penelitian ini menggunakan Rancangan Acak Lengkap (RAL) faktorial yang terdiri dari 2 faktor, faktor pertama adalah pemberian Herbafarm $(\mathrm{H})$ yang terdiri dari 4 taraf yaitu $0,1.5,3$, $4.5 \mathrm{cc} / \mathrm{L}$ air, dan faktor kedua adalah NPK Mutiara 16:16:16 (N) yang terdiri dari 4 taraf perlakuan yaitu $0,10.8,21.6,32.4$ gram/plot, sehingga terdapat 16 kombinasi perlakuan dengan 3 ulangan maka terdapat 48 plot unit percobaan. Masing-masing unit percobaan terdiri dari 12 tanaman dan 2 diantaranya dijadikan tanaman sampel, sehingga keseluruhan tanaman 576 tanaman.Perlakuan terbaik pemberin herbafarm $3 \mathrm{cc} / \mathrm{l}$ air dan pupuk NPK mutiara 21,6 g/plot $\left(\left(\mathrm{H}_{2} \mathrm{~N}_{2}\right)\right.$ dengan hasil terbaik kecepatan pengisian bahan kering $0,33 \mathrm{~g}$, persentase polong bernas pertanaman $71,33 \%$, berat biji kering panen pertanaman 27,50 gram. Pengaruh utama pemberian herbafarm $3 \mathrm{cc} / \mathrm{l}$ air memberikan hasil terbaik pada tinggi tanaman $65,67 \mathrm{~cm}$, umur berbunga 31,92 hari,waktu pengisian efektif 19,74 hari dan berat 100 biji 5,99 gram. Sedangkan pemberian pupuk NPK mutiara 21,6 $\mathrm{g} /$ plot memberikan hasil terbaik pada tinggi tanaman $61,67 \mathrm{~cm}$ dan waktu pengisian efektif 19,90 hari, namun pemberian pupuk NPK mutiara 32,4 g/plot memberikan hasil terbaik pada umur berbunga 32,26 hari dan berat 100 biji 5,96 gram.
\end{abstract}

Kata Kunci : Herbafarm, Pertumbuhan, Produksi, Kacang Hijau. 


\section{PENDAHULUAN}

Kacang hijau merupakan salah satu tanaman palawija yang tergolong pada kacangkacangan. Tumbuhan yang termasuk suku polong-polongan ini memiliki banyak manfaat dalam kehidupan sehari-hari.Kandungan proteinnya cukup tinggi dan merupakan sumber mineral penting seperti kalsium dan fosfor yang sangat diperlukan tubuh. Kacang hijau memiliki urutan ketiga setelah kedelai dan kacang tanah sebagai tanaman pangan.

Berdasarkan Badan Pusat Statistik Provinsi Riau pada tahun 2011 dengan luas panen mencapai 938 Ha dengan produksi 995 ton, pada tahun 2012 dengan luas panen mencapai 865 Ha dengan produksi 920 ton, pada tahun 2013 dengan luas panen $585 \mathrm{Ha}$ dengan produksi 619 ton, pada tahun 2014 dengan luas panen mencapai 598 Ha dengan produksi 645 ton, di tahun 2015 dengan luas panen 576 Ha mencapai 598 ton. Berdasarkan data diatas produktivitas kacang hijau masih tergolong rendah dan mengalami fruktuasi (Anonimus, 2016)

Sebagian besar wilayah Riau memiliki lahan PMK (Podzolik Merah Kuning). Tanah PMK memiliki karakteristik daya simpan unsur hara yang sangat rendah, kejenuhan unsur basa seperti $\mathrm{Ca}, \mathrm{Mg}$ dan $\mathrm{K}$ yang rendah sehingga tidak cocok untuk tanaman semusim, daya simpan air yang sangat rendah sehingga mudah mengalami kekeringan, kadar bahan organik yang rendah dan hanya terdapat di permukaan tanah.

Di Riau tingkat kesuburan tanah rendah, sehingga mengakibatkan produksi kacang hijau masih rendah. Untuk meningkatkan produksi kacang hijau yang maksimal dapat dilakukan perbaikan teknik budidaya seperti pemupukan.

Pupuk herbafarm cair merupakan pupuk organik yang mampu meningkatkan imunitas (daya tahan tubuh) dan adaptasi terhadap kondisi lingkungan yang tidak ideal karena mengandung Bio-Protectant sehingga tanaman mampu memaksimalkan kondisi cuaca dan iklim untuk menghasilkan pertumbuhan dan produksi maksimal. Selain itu, herbafarm cair mengandung unsur hara makro dan mikro serta jenis mikroorganisme pengkaya nutrisi alam yang juga mampu memperbaiki sifat fisik, kimia dan biologi tanah.
Untuk mendapatkan pertumbuhan sehingga menghasilkan produksi kacang hijau yang maksimal. Maka asupan unsur hara harus ditingkatkan dengan pemberian pupuk anorganik untuk memenuhi kebutuhan unsurunsur tersebut.

Pemberian pupuk anorganik juga dilakukan diantaranya pupuk NPK Mutiara. Pupuk NPK Mutiara merupakan jenis pupuk majemuk yang mengandung unsur $\mathrm{N} 16 \%, \mathrm{P}$ $16 \%, \mathrm{~K} 16 \%$ dan beberapa unsur mikro yang dibutuhkan dalam jumlah relatif sedikit.

Penggunaan herbafarm dapat memperbaiki sifat fisik, kimia dan biologi tanah sehingga kesuburan tanah dapat meningkat, sedangkan penggunaan pupuk NPK Mutiara 16:16:16 dimanfaatkan untuk melengkapi kebutuhan unsur hara bagi tanaman. Kombinasi penggunaan herbafarm dan pupuk NPK Mutiara 16:16:16 dapat meningkatkan pertumbuhan dan produksi kacang hijau.

Berdasarkan permasalahan yang telah diungkapkan, maka penulis telah melakukan penelitian dengan judul "Pengaruh Herbafarm dan NPK Mutiara 16:16:16 terhadap Pertumbuhan dan Produksi Tanaman Kacang Hijau (Vigna radiata L.)”.

\section{METODE PENELITIAN}

Penitian ini telah dilaksanakan di kebun percobaan Fakultas Pertanian Universitas Islam Riau Jl. Kharuddin Nasution KM 11, Kelurahan Air Dingin, Kecamatan Bukit Raya Kota Pekanbaru.Selama 4 bulan mulai bulan Januari sampai April 2018.

Bahan-bahan yang digunakan dalam penelitian ini adalah kacang hijau varietas vima-1 (Deskripsi varietas pada Lampiran 2), Pupuk Bio Organik Herbafarm, Pupuk NPK Mutiara 16:16:16, Furadan 3G, Decis 25 EC, antrakol, Alat yang digunakan dalam penelitian ini adalah cangkul, garu, handsprayer, timbangan, meteran, penggaris, gembor, gergaji, kuas, martil, kamera dan alat-alat tulis.

Penelitian ini menggunakan Rancangan Acak Lengkap (RAL) faktorial yang terdiri dari 2 faktor yaitu $\mathrm{H}$ (Herbafarm) dengan 4 taraf perlakuan dan N (NPK Mutiara 16:16:16) dengan 4 taraf perlakuan, sehingga didapat 16 kombinasi perlakuan.Pada masing-masing perlakuan dilakukan 3 ulangan sehingga didapat 
48 plot. Setiap plot terdapat 12 tanaman dengan 2 tanaman sebagai sampel sehingga jumlah keseluruhan tanaman adalah 576 tanaman.

Adapun perlakuan adalah Faktor Pemberian Herbafarm $(\mathrm{H})$ yang terdiri dari 4 taraf, yaitu: $\mathrm{H}_{0}$ : Tanpa pemberian Herbafarm, $\mathrm{H}_{1}$ : Konsentrasi Herbafarm 1,5 cc/liter air, $\mathrm{H}_{2}$ : Konsentrasi Herbafarm 3 cc/liter air, $\mathrm{H}_{3}$ : Konsentrasi Herbafarm 4,5 cc/liter air. Faktor Pemberian Pupuk NPK Mutiara 16:16:16 (N) ada 4 taraf, yaitu: $\mathrm{N}_{0}$ : Tanpa pemberian Pupuk NPK Mutiara 16:16:16, $\mathrm{N}_{1}$ : NPK Mutiara 16:16:16 dosis 10,8 g/plot (100 kg/ha), $\mathrm{N}_{2}$ : NPK Mutiara 16:16:16 dosis 21,6 g/plot (200 $\mathrm{kg} / \mathrm{ha}$ ), $\mathrm{N}_{3}$ : NPK Mutiara 16:16:16 dosis 32,4 $\mathrm{g} /$ plot $(300 \mathrm{~kg} / \mathrm{ha})$.

Pemberian Herbafarm dilakukan pada waktu sore hari, herbafarm diberikan dengan cara disiram pada sekeliling batang tanaman dan permukaan tanah dengan volume pemberian yaitu $1000 \mathrm{ml}$ air perplot pada pemberian pertama umur $14 \mathrm{HST}, 1500 \mathrm{ml}$ air perplot pemberian kedua umur 21 HST, 2000 $\mathrm{ml}$ air perplot pemberian ketiga umur 28 HST dan $2500 \mathrm{ml}$ air perplot pada pemberian keempat umur 35 HST. Herbafarm diberikan sebanyak 4 kali selama penelitian dengan interval 1 minggu sekali.Pupuk NPK Mutiara diberikan 1 kali bersamaan dengan penanaman kacang hijau. Pemberian dilakukan dengan cara larikan diantara barisan tanam.

\section{HASIL DAN PEMBAHASAN}

\section{Tinggi Tanaman $(\mathrm{cm})$}

Hasil pengamatan tinggi tanaman setelah dilakukan analisis sidik ragam, memperlihatkan bahwa secara interaksi pemberian herbafarm dan pupuk NPK Mutiara16:16:16 tidak berpengaruh nyata terhadap tinggi tanaman kacang hijau, namun secara utama berpengaruh nyata. Rata-rata tinggi tanaman kacang hijau dapat dilihat pada Tabel 1.

Tabel 1. Rata-rata tinggi tanaman kacang hijau dengan pemberian Herbafarm dan Pupuk NPK Mutiara 16:16:16 (cm) umur 28 HST.

\begin{tabular}{|c|c|c|c|c|c|}
\hline \multirow{2}{*}{$\begin{array}{l}\text { Herbafarm } \\
\text { cc/l air }\end{array}$} & \multicolumn{4}{|c|}{ Pupuk NPK Mutiara 16:16:16 (g/plot) } & \multirow[b]{2}{*}{ Rerata } \\
\hline & $0\left(\mathrm{~N}_{0}\right)$ & $10,8\left(\mathrm{~N}_{1}\right)$ & $21,6\left(\mathrm{~N}_{2}\right)$ & $32,4\left(\mathrm{~N}_{3}\right)$ & \\
\hline $0\left(\mathrm{H}_{0}\right)$ & 57,67 & 58,00 & 58,33 & 59,67 & $58,17 \mathrm{~b}$ \\
\hline $1,5\left(\mathrm{H}_{1}\right)$ & 58,00 & 58,83 & 59,00 & 59,33 & $58,92 \mathrm{~b}$ \\
\hline $3,0\left(\mathrm{H}_{2}\right)$ & 59,67 & 66,83 & 68,67 & 67,50 & $65,67 \mathrm{a}$ \\
\hline $4,5\left(\mathrm{H}_{3}\right)$ & 59,00 & 59,93 & 60,00 & 60,33 & $59,82 \mathrm{~b}$ \\
\hline Rerata & $58,58 \mathrm{~b}$ & $60,86 \mathrm{ab}$ & $61,67 a$ & $61,46 \mathrm{a}$ & \\
\hline $\mathrm{KK}=3,99 \%$ & & BNJ H & $=2,69$ & & \\
\hline
\end{tabular}

Angka-angka pada baris yang diikuti huruf kecil yg sama menunjukkan tidak berbeda nyata menurut uji lanjut Beda Nyata Jujur (BNJ) pada taraf $5 \%$.

Pada Tabel 1 menunjukkan bahwa secara utama pemberian herbafarm dan pupuk NPK Mutiara 16:16:16 memberikan pengaruh yang berbeda nyata terhadap tinggi tanaman kacang hijau, dimana pemberian herbafarm $3 \mathrm{cc} / \mathrm{l}$ air $\left(\mathrm{H}_{2}\right)$ memberikan hasil terbaik yaitu $65,67 \mathrm{~cm}$. perlakuan ini berbeda nyata dengan perlakuan lainnya. Sedangkan pengaruh utama pemberian pupuk NPK Mutiara 21,6 g/plot $\left(\mathrm{N}_{2}\right)$ dengan tinggi tanaman terbaik $61,67 \mathrm{~cm}$, tidak berbeda nyata dengan $\left(\mathrm{N}_{3}\right)$ yaitu $61,46 \mathrm{~cm}$ tetapi bebeda nyata dengan perlakuan lainnya. Ini disebabkan pemberian herbafarm mampu memperbaiki sifat fisik dan kimia tanah, sehingga memberikan pertumbuhan perakaran yang baik. Pemberian herbafarm dan pupuk NPK mutiara 16:16:16 merupakan kombinasi perlakuan yang menghasilkan tinggi tanaman terbaik dari kontrol, kombinasi perlakuan $\mathrm{H}_{2} \mathrm{~N}_{2}$ dapat meningkatkan tinggi tanaman mencapai 15, 67 $\%$ dari deskripsi, hal ini diduga pemberian herbafarm dan pupuk NPK Mutiara dapat meningkatkan pertumbuhan tinggi tanaman karena unsur hara ditanah tersedia dengan jumlah yang cukup sehingga mampu memenuhi kebutuhan hara tanaman.

Hal ini juga dapat disebabkan unsurunsur yang terdapat pada pupuk cair Herbafarm yang dibutuhkan untuk dapat menyuplai hara yang dibutuhkan tanaman agar dapat tumbuh dengan baik, salah satunya memiliki kandungan hara N yaitu: 2,24 \%, Sehingga dengan aplikasi 
pada tanaman lebih menghasilkan pertumbuhan dan perkembangan tanaman yang lebih baik.

Menurut Samekto (2006) dalam pupuk Herbafarm ditambahnya unsur mikro dalam bentuk kelat, dengan zat aktif cairan ganggang atau asam humat sesuai dengan kebutuhan, supaya kandungan hara esensial seimbang. Dengan pengaplikasian pada tanaman, maka akan memberikan pertumbuhan dan perkembangan tanaman yang optimal.

Selain itu, juga dikarenakan penyerapan hara $\mathrm{N}$ dan $\mathrm{P}$ yang diberikan pada tanaman terpenuhi dengan optimal, akibat baiknya pertumbuhan perakaran tanaman. Hal ini sesuai dengan pendapat Bagaskara (2011) dalam Mallatina (2016) bahwa unsur makro N, P, dan $\mathrm{K}$ mempunyai peranan masing-masing untuk tanaman diantaranya unsur nitrogen dibutuhkan untuk pertumbuhan daun dan pembentukan batang serta cabang. Khusus pada kacangkacangan yang memiliki nodul akar, dapat memanfaatkan bakteri yang ada di udara. Unsur fosfor diperlukan bagi tanaman untuk perkembangan biji dan akar. Sementara unsur kalium berfungsi untuk membentuk bunga dan buah serta membantu tanaman melawan penyakit. Rinsema (2004) mengemukakan tanaman yang kekurangan unsur $\mathrm{P}$ warna daun menjadi hijau tua, kadang-kadang menjadi warna ungu, pertumbuhan terhambat dan batangnya menjadi kerdil, pembentukan biji terhambat.

Martono dan Paulus (2005) menyatakan bahwa pemberian pupuk yang mengandung $\mathrm{N}$, $\mathrm{P}, \mathrm{K}$ dengan dosis yang sesuai akan berpengaruh dalam mempercepat pertumbuhan untuk menambah tinggi tanaman secara maksimal sedangkan pemberian dosis terlalu tinggi akan memperlambat pertumbuhan tanaman begitu pula dengan pemberian terlalu rendah akan menyebabkan defisiensi hara yang berpengaruh terhadap pertumbuhan tanaman sehingga menjadi kerdil. Selanjutnya Prasetya dkk (2009) menjelaskan bahwa unsur nitrogen bermanfaat untuk pertumbuhan vegetatif tanaman yaitu pembentukan sel-sel baru seperti daun, cabang, dan mengganti sel-sel yang rusak.

\section{Umur Berbunga (hari)}

Dari hasil pengamatan umur berbunga setelah dilakukan analisis sidik ragam, memperlihatkan bahwa secara interaksi pemberian herbafarm dan pupuk NPK Mutiara 16:16:16 tidak berpengaruh nyata terhadap umur berbunga, namun secara utama memberikan pengaruh yang nyata. Rata-rata umur berbunga dapat dilihat pada Tabel 2 .

Tabel 2. Rata-rata umur berbunga kacang hijau dengan pemberian Herbafarm dan Pupuk NPK Mutiara 16:16:16 (Hari).

\begin{tabular}{llcccc}
\hline \multirow{2}{*}{$\begin{array}{c}\text { Herbafarm } \\
\text { cc/l air }\end{array}$} & \multicolumn{4}{c}{ Pupuk NPK Mutiara 16:16:16 (g/plot) } & Rerata \\
\cline { 2 - 5 } & $0\left(\mathrm{~N}_{0}\right)$ & $10,8\left(\mathrm{~N}_{1}\right)$ & $21,6\left(\mathrm{~N}_{2}\right)$ & $32,4\left(\mathrm{~N}_{3}\right)$ & $35,78 \mathrm{c}$ \\
\hline $0\left(\mathrm{H}_{0}\right)$ & 35,83 & 35,80 & 35,77 & 35,70 & $33,93 \mathrm{~b}$ \\
$1,5\left(\mathrm{H}_{1}\right)$ & 35,67 & 34,70 & 33,67 & 31,67 & $31,92 \mathrm{a}$ \\
$3,0\left(\mathrm{H}_{2}\right)$ & 35,00 & 32,00 & 30,00 & 30,67 & $32,58 \mathrm{ab}$ \\
$4,5\left(\mathrm{H}_{3}\right)$ & 35,33 & 32,67 & 31,33 & 31,00 & \\
\hline Rerata & $35,46 \mathrm{~b}$ & $33,79 \mathrm{ab}$ & $32,69 \mathrm{a}$ & $32,26 \mathrm{a}$ & \\
\hline KK $=4,98 \%$ & \multicolumn{5}{c}{ BNJ H\&N = 1,85 } \\
\hline
\end{tabular}

Angka-angka pada baris yang diikuti huruf kecil yg sama menunjukkan tidak berbeda nyata menurut uji lanjut Beda Nyata Jujur (BNJ) pada taraf $5 \%$.

Pada Tabel 2 menunjukkan bahwa secara utama pemberian herbafarm dan pupuk NPK Mutiara 16:16:16 memberikan pengaruh yang berbeda nyata terhadap umur berbunga tanaman kacang hijau, dimana umur berbunga tercepat pada pemberian herbafarm dengan $3 \mathrm{cc} / \mathrm{l}$ air $\left(\mathrm{H}_{2}\right)$ memberikan hasil terbaik 31,92 hari. Perlakuan ini tidak berbeda nyata dengan perlakuan H3 dengan dosis 4,5 cc/liter air dengan hasil yaitu 32,58 hari, namun berbeda nyata dengan perlakuan lainnya. Sedangkan perlakuan Pupuk NPK Mutiara dengan dosis $32,4 \mathrm{~g} /$ plot $\left(\mathrm{N}_{3}\right)$ memberikan hasil terbaik pada umur berbunga yaitu 32,26 hari perlakuan ini tidak berbeda nyata dengan perlakuan $\left(\mathrm{N}_{2}\right)$ dengan umur berbungan 32,69 hari.

Lebih cepatnya umur berbunga pada perlakuan $\mathrm{H}_{2} \mathrm{~N}_{3}$ dibandingkan dengan perlakuan lainnya, ini dikarenakan herbafarm yang 
diberikan mampu memberikan tingkat kesuburan tanah yang baik dan didukung dengan kandungan unsur hara $\mathrm{P}$ yang lebih banyak, sehingga mampu memberikan kebutuhan nutrisi yang lebih optimal dibandingkan dengan perlakuan lainnya.

Alfandi (2014), Fase generatif terjadi pada umur 35 HST ditandai dengan munculnya bunga pada ketiak-ketia daun yang berkembang menjadi bunga dewasa bewarna kuning dan menjadi polong. Munculnya bunga pada satu tanaman tidak serempak sehingga pemanenan tidak dapat dilaksanakan sekaligus.Panen dilakukan setelah umur 60 HST setelah polong berwarna hitam.

Amilia (2005), Herbafarm selain mampu meningkatkan sistem distribusi dan asupan hara, juga mampu meningkatkan daya adaptasi tanaman terhadap faktor lingkungan yang kritis sekalipun karena mengandung hara lengkap, mikroba penyedia nutrisi dan pengurai yang dilengkapi dengan zat Bio-Protectant.

Unsur hara yang dibutuhkan tanaman pada fase generatif ialah unsur $P$ yang berperan dalam pembentukan bunga dan buah. Jika kebutuhan unsur P terpenuhi secara maksimal, maka proses pembungaan dan pembuahan akan semakin cepat. Sementara unsur K berperan dalam pembentukan karbohidrat dan gula yang berfungsi untuk membentuk kualitas bunga dan buah yang dihasilkan akan lebih baik. Intinya pupuk $\mathrm{K}$ juga diperlukan tanaman untuk perkuat kondisi tanaman agar tidak mudah terserang hama dan penyakit (Sutedjo, 2010).

Harjadi (1991) dalam Suhartono (2006) mengemukakan bahwa karbohidrat sangat dibutuhkan untuk pertumbuhan vegetatif dan generatif tanaman dimana karbohidrat dapat digunakan untuk pertumbuhan batang, daun, perakaran dan juga berguna untuk pertumbuhan bunga, buah dan biji.Unsur hara yang dibutuhkan tanaman pada fase generatif ialah unsur $\mathrm{P}$, yang berperan dalam pembentukan bunga dan buah. Jika kebutuhan unsur $P$ terpenuhi secara maksimal, maka proses pembungaan dan pembuahan akan semakin cepat.

Nursanti (2008), jumlah pemberian pupuk terutama pupuk organik akan menentukan tingkat ketersediaan hara dan kondisi perbaikan sifat-sifat tanah. Menurut Hayati dkk (2012), Pupuk organik mempunyai fungsi antara lain memperbaiki struktur tanah, karena bahan organik dapat mengikat partikel tanah menjadi agregat yang mantap, memperbaiki distribusi ukuran pori tanah sehingga daya pegang air tanah meningkat dan pergerakan udara didalam tanah menjadi lebih baik. Fungsi biologi pupuk organik adalah sebagai sumber energi dan makanan bagi mikroba di dalam tanah. Dengan ketersediaan bahan organik yang cukup, aktivitas organisme tanah yang juga mempengaruhi ketersediaan hara, siklus hara, dan pembentukan pori mikro dan makro tanah menjadi lebih baik. Kemampuan pupuk organik murni walaupun kuantitasnya sangat sedikit tetapi mampu memberikan pengaruh besar pada tanah yang salah satunya bisa bermanfaat untuk mempercepat panen. Hal ini dikarenan kadar haranya tepat untuk kebutuhan tanaman dan penggunaannya lebih efektif dan efisien.

Hidayat (2010), kegiatan metabolisme didalam tubuh tumbuhan seperti fotosintesis dan pembentukan primordial bunga dan inisiasi bunga salah satu dipengaruhi oleh pemenuhan unsur hara.

\section{Kecepatan Pengisian Bahan Kering Biji (mg/biji/hari)}

Dari hasil pengamatan kecepatan pengisian bahan kering biji setelah dilakukan analisis sidik ragam, memperlihatkan bahwa secara interaksi maupun pengaruh utama pemberian herbafarm dan pupuk NPK Mutiara 16:16:16 berpengaruh nyata. Rata-rata kecepatan pengisian bahan kering biji dapat di lihat pada Tabel 3 .

Pada Tabel 3 menunjukkan bahwa secara interaksi perlakuan herbafarm dan pupuk NPK Mutiara 16:16:16 memberikan pengaruh nyata terhadap kecepatan peengisian bahan kering, dimana perlakuan terbaik pada herbafarm $3 \mathrm{cc} / \mathrm{l}$ air dan pupuk NPK Mutiara 21,6 g/plot dengan kecepatan pengisian bahan kering yaitu; $0,33 \mathrm{~g}$ $\left(\mathrm{H}_{2} \mathrm{~N}_{2}\right)$. Perlakuan ini berbeda nyata dengan perlakuan lainnya. Ini dikarenakan ketersediaan hara pada tanaman akan mempengaruhi kecepatan pengisian bahan kering pada tanaman, semakin baik kandungan hara dalam tanah maka memberikan perkembangan yang baik pada tanaman, sehingga berdampak pada pengisian bahan kering tanaman.Tingginya angka pengamatan kecepatan pengisian bahan 
kering biji dengan perlakuan $\mathrm{H}_{2} \mathrm{~N}_{2}$ diduga telah memenuhi kebutuhan hara tanaman kacang hijau untuk mengisi bahan kering biji.

Tabel 3. Rata-rata kecepatan pengisian bahan kering biji dengan pemberian Herbafarm dan Pupuk NPK Mutiara 16:16:16(mg/biji/hari).

\begin{tabular}{llllll}
\hline \multirow{2}{*}{$\begin{array}{c}\text { Herbafarm } \\
\text { cc/l air }\end{array}$} & \multicolumn{4}{c}{ Pupuk NPK Mutiara 16:16:16 (g/plot) } & \\
\cline { 2 - 5 } & $0\left(\mathrm{~N}_{0}\right)$ & $10,8\left(\mathrm{~N}_{1}\right)$ & $21,6\left(\mathrm{~N}_{2}\right)$ & $32,4\left(\mathrm{~N}_{3}\right)$ & Rerata \\
\hline $0\left(\mathrm{H}_{0}\right)$ & $0,02 \mathrm{~d}$ & $0,07 \mathrm{~cd}$ & $0,14 \mathrm{bc}$ & $0,15 \mathrm{bc}$ & $0,10 \mathrm{c}$ \\
$1,5\left(\mathrm{H}_{1}\right)$ & $0,07 \mathrm{~cd}$ & $0,18 \mathrm{~b}$ & $0,19 \mathrm{~b}$ & $0,17 \mathrm{~b}$ & $0,15 \mathrm{~b}$ \\
$3,0\left(\mathrm{H}_{2}\right)$ & $0,14 \mathrm{bc}$ & $0,19 \mathrm{~b}$ & $0,33 \mathrm{a}$ & $0,17 \mathrm{~b}$ & $0,21 \mathrm{a}$ \\
$4,5\left(\mathrm{H}_{3}\right)$ & $0,05 \mathrm{~cd}$ & $0,07 \mathrm{~cd}$ & $0,16 \mathrm{bc}$ & $0,11 \mathrm{c}$ & $0,10 \mathrm{c}$ \\
\hline Rerata & $0,07 \mathrm{c}$ & $0,13 \mathrm{~b}$ & $0,21 \mathrm{a}$ & $0,15 \mathrm{~b}$ & \\
\hline
\end{tabular}

$\mathrm{KK}=14,02 \% \quad \mathrm{BNJ} \mathrm{HN}=0,06 \quad$ BNJ H\&N $=0,02$

Angka-angka pada baris yang diikuti huruf kecil yg sama menunjukkan tidak berbeda nyata menurut uji lanjut Beda Nyata Jujur (BNJ) pada taraf 5\%.

Faktor yang menjamin kesuburan tanah ialah ketersediaan bahan organik yang ada di dalam tanah dan jasat renik yang menguntungkan dalam perakaran tanaman. Jika bahan organik dalam tanah berada dalam keadaan yang seimbang, maka akan memberikan pertumbuhan dan perkembangan tanaman yang baik, sehingga tanaman akan tumbuh dengan optimal (Musnawar, 2005).

Unsur fosfor yang terkandung dalam pupuk NPK Mutiara 16:16:16 berperan penting dalam pertumbuhan generatif tanaman kacang hijau salah satu kecepatan pengisian bahan kering biji. Munir (2004) mengemukakan dengan ketersedian unsur hara fosfat yang cukup maka meningkatkan laju fotosintesis sehingga asimilat yang dihasilkan sebagian dimanfaatkan bagi pertumbuhan serta penyusunan organ tanaman seperti batang dan sisanya disimpan dalam bentuk protein serta karbohidrat dalam bentuk biji tanaman (Iswanda, 2018).

Hasil fotosintesis pada tanaman mulamula digunakan untuk pertumbuhan vegetatif kemudian membentuk organ generatif. Protein dibentuk pada akhirnya disimpan dalam biji sebagai lanjutan proses fotosintesis yang

semula dipakai untuk menyusun pertumbuhan vegetatif. Setelah pertumbuhan vegetatif berhenti dipindahkan menjadi penimbunan protein didalam biji sebagai cadangan makanan (Lingga, 2007 dalam Buana, 2016).

Rasyad (2014) mengemukakan bahwa beberapa faktor lingkungan seperti temperatur, intensitas cahaya, kadar air dan pemberian pupuk sangat mempengaruhi perkembangan biji. Intensitas cahaya yang tinggi juga mempercepat laju pertumbuhan bahan kering biji beberapa tanaman tetapi tidak mempengaruhi waktu pengisian bahan kering efektif, sebaliknya cahaya yang rendah menyebabkan laju asimilat lebih lambat sehingga mempengaruhi terhadap hasil biji.

\section{Waktu Pengisian Efektif (Hari)}

Dari hasil pengamatan waktu pengisian efektif kacang hijau setelah dilakukan analisis sidik ragam, memperlihatkan bahwa secara interaksi pemberian herbafarm dan pupuk NPK Mutiara 16:16:16 tidak berpengaruh nyata terhadap waktu pengisian efektif, namun secara utama memberikan pengaruh nyata. Rata-rata waktu pengisian efektif dapat dilihat pada Tabel 4.

Pada Tabel 4 menunjukkan bahwa secara utama pemberian herbafarm dan pupuk NPK Mutiara 16:16:16 memberikan pengaruh yang berbeda nyata terhadap waktu pengisian efektif, dimana perlakuan terbaik pada pemberian Herbafarm $3 \mathrm{cc} / \mathrm{l}$ air $\left(\mathrm{H}_{2}\right)$ yaitu 19,74 hari, tidak berbeda nyata dengan $\mathrm{H}_{3}$ yaitu 20,96 hari namun berbeda nyata dengan perlakuan lainnya. Sedangkan pupuk NPK Mutiara 21,6 g/plot dengan persentase polong berisi penuh mencapai 19,90 hari. Ini dikarenakan unsur hara yang diserap akar tanaman sebagai bahan makanan diproses dijaringan daun, kemudian ditranslokasikan keseluruh jaringan tanaman untuk memacu pertumbuhan vegetatif dan generatif tanaman. 
Tabel 4. Rata-rata waktu pengisian efektif pada kacang hijau dengan pemberian herbafarm dan pupuk NPK Mutiara 16:16:16 (Hari).

\begin{tabular}{|c|c|c|c|c|c|}
\hline \multirow{2}{*}{$\begin{array}{l}\text { Herbafarm } \\
\text { cc/l air }\end{array}$} & \multicolumn{4}{|c|}{ Pupuk NPK Mutiara 16:16:16 (g/plot) } & \multirow[b]{2}{*}{ Rerata } \\
\hline & $0\left(\mathrm{~N}_{0}\right)$ & $10,8\left(\mathrm{~N}_{1}\right)$ & $21,6\left(\mathrm{~N}_{2}\right)$ & $32,4\left(\mathrm{~N}_{3}\right)$ & \\
\hline $0\left(\mathrm{H}_{0}\right)$ & 24,67 & 24,18 & 22,31 & 23,89 & $23,76 \mathrm{c}$ \\
\hline $1,5\left(\mathrm{H}_{1}\right)$ & 23,53 & 22,17 & 21,67 & 21,97 & $22,33 b$ \\
\hline $3,0\left(\mathrm{H}_{2}\right)$ & 21,45 & 20,66 & 17,00 & 19,85 & $19,74 \mathrm{a}$ \\
\hline $4,5\left(\mathrm{H}_{3}\right)$ & 22,80 & 21,89 & 18,63 & 20,50 & $20,96 \mathrm{ab}$ \\
\hline Rerata & $23,11 \mathrm{c}$ & $22,23 b$ & $19,90 \mathrm{a}$ & $21,55 b$ & \\
\hline
\end{tabular}

Angka-angka pada baris yang diikuti huruf kecil yg sama menunjukkan tidak berbeda nyata menurut uji lanjut Beda Nyata Jujur (BNJ) pada taraf 5\%.

Juliandi (2016) mengemukakan bahwa fosfor bagi tanaman juga dapat memperbaiki pertumbuhan generatif terutama pembentukan bunga, buah dan biji.Unsur $\mathrm{P}$ pada Leguminosae dapat merangsang pembentukan bintil akar dan kerja simbiosis bakteri Rhizobium sp sehingga menambah hasil fiksasi unsur $\mathrm{N}$ yang dibutuhkan dalam pertumbuhan vegetatif tanaman.Apabila pertumbuhan vegetatif baik, fotosintesis semakin banyak, hal ini dapat menyebabkan kemampuan tanaman untuk membentuk organ generatif semakin meningkat.

\section{Persentase Polong Bernas Per Tanaman (\%)}

Dari hasil pengamatan persentase polong bernas per tanaman setelah dilakukan analisis sidik ragam, memperlihatkan bahwa secara interaksi maupun pengaruh utama pemberian herbafarm dan pupuk NPK Mutiara 16:16:16 berpengaruh nyata terhadap persentase polong bernas per tanaman. Rata-rata persentase polong bernas per tanaman dapat dilihat pada Tabel 5.

Tabel 5. Rata-rata persentase polong bernas per tanaman kacang hijau dengan pemberian herbafarm dan pupuk NPK Mutiara 16:16:16 (\%).

\begin{tabular}{|c|c|c|c|c|c|}
\hline \multirow{2}{*}{$\begin{array}{l}\text { Herbafarm } \\
\text { cc/l air }\end{array}$} & \multicolumn{4}{|c|}{ Pupuk NPK Mutiara 16:16:16 (g/plot) } & \multirow[b]{2}{*}{ Rerata } \\
\hline & $0\left(\mathrm{~N}_{0}\right)$ & $10,8\left(\mathrm{~N}_{1}\right)$ & $21,6\left(\mathrm{~N}_{2}\right)$ & $32,4\left(\mathrm{~N}_{3}\right)$ & \\
\hline $0\left(\mathrm{H}_{0}\right)$ & $53,55 \mathrm{~d}$ & $58,67 \mathrm{c}$ & $66,00 \mathrm{~b}$ & $60,66 \mathrm{c}$ & $59,72 \mathrm{c}$ \\
\hline $1,5\left(\mathrm{H}_{1}\right)$ & $62,33 \mathrm{bc}$ & $63,22 \mathrm{bc}$ & $66,55 \mathrm{~b}$ & $64,33 \mathrm{bc}$ & $64,11 \mathrm{~b}$ \\
\hline $3,0\left(\mathrm{H}_{2}\right)$ & $67,75 \mathrm{ab}$ & $69,44 a b$ & $71,33 \mathrm{a}$ & $69,67 \mathrm{ab}$ & $69,55 \mathrm{a}$ \\
\hline $4,5\left(\mathrm{H}_{3}\right)$ & $63,67 \mathrm{bc}$ & $64,55 \mathrm{bc}$ & $67,89 \mathrm{ab}$ & $66,37 \mathrm{~b}$ & $65,62 \mathrm{~b}$ \\
\hline Rerata & $61,83 \mathrm{c}$ & $63,97 \mathrm{~b}$ & $67,94 \mathrm{a}$ & $65,26 \mathrm{~b}$ & \\
\hline
\end{tabular}

$\mathrm{KK}=2,21 \% \quad \mathrm{BNJ} \mathrm{HN}=4,35 \quad$ BNJ H\&N $=1,58$

Angka-angka pada baris yang diikuti huruf kecil yg sama menunjukkan tidak berbeda nyata menurut uji lanjut Beda Nyata Jujur (BNJ) pada taraf 5\%.

Pada Tabel 5 menunjukkan bahwa secara interaksi pemberian herbafarm dan pupuk NPK Mutiara 16:16:16 memberikan pengaruh yang berbeda nyata terhadap persentase polong berisi penuh, dengan perlakuan terbaik pada pemberian herbafarm $3 \mathrm{cc} / \mathrm{l}$ air dan pupuk NPK Mutiara 21,6 g/plot dengan persentase polong berisi penuh mencapai $71,33 \%$. Ini dikarenakan pemberian herbafarm memberikan daya serap akar yang baik dalam memenuhi kebutuhan hara untuk pertumbuhan dan perkembangan tanaman kacang hijau. Selain itu, pemberian pupuk NPK Mutiara 16:16:16 untuk memenuhi kebutuhan hara esensial sehingga kombinasi perlakuan tersebut saling mendukung dan melengkapi kekurangan yang dibutuhkan tanaman.

Jumlah polong bernas per tanaman dan jumlah biji bernas per tanaman sangat menentukan produktivitas tanaman kacang hijau. Menurut Anwari dan Iswanto (2004) dalam Fauzia (2016), jumlah polong per tanaman kacang hijau adalah 16 polong, sedangkan Anwari (2008), menyebutkan kisaran yang lebih besar yaitu antara 11-51 polong. Tingginya persentase polong bernas pertanaman dengan pemberian herbafarm dan 
pupuk NPK Mutiara 16:16:16 diduga merupakan dosis yang tepat dan seimbang untuk tanaman kacang hijau.

\section{Berat Biji Kering Pertanaman (gram)}

Dari hasil pengamatan berat biji kering per tanaman setelah dilakukan analisis sidik ragam, memperlihatkan bahwa secara interaksi maupun pengaruh utama pemberian herbafarm dan pupuk NPK Mutiara 16:16:16 berpengaruh nyata terhadap berat biji kering per tanaman. Rata-rata berat biji kering per tanaman dapat dilihat pada Tabel 6.

Tabel 6. Rata-rata berat biji kering per tanaman dengan pemberian herbafarm dan pupuk NPK Mutiara 16:16:16 (gram).

\begin{tabular}{|c|c|c|c|c|c|}
\hline \multirow{2}{*}{$\begin{array}{c}\text { Herbafarm } \\
\text { cc/l air }\end{array}$} & \multicolumn{4}{|c|}{ Pupuk NPK Mutiara 16:16:16 (g/plot) } & \multirow[b]{2}{*}{ Rerata } \\
\hline & $0\left(\mathrm{~N}_{0}\right)$ & $10,8\left(\mathrm{~N}_{1}\right)$ & $21,6\left(\mathrm{~N}_{2}\right)$ & $32,4\left(\mathrm{~N}_{3}\right)$ & \\
\hline $0\left(\mathrm{H}_{0}\right)$ & $22,00 \mathrm{c}$ & $22,17 \mathrm{c}$ & $22,50 \mathrm{c}$ & $22,33 \mathrm{c}$ & $22,25 \mathrm{~d}$ \\
\hline $1,5\left(\mathrm{H}_{1}\right)$ & $23,17 \mathrm{c}$ & $23,33 \mathrm{bc}$ & $24,67 \mathrm{bc}$ & $24,50 \mathrm{bc}$ & $23,92 \mathrm{c}$ \\
\hline $3,0\left(\mathrm{H}_{2}\right)$ & $23,67 \mathrm{bc}$ & $25,50 \mathrm{ab}$ & $27,50 \mathrm{a}$ & $25,67 \mathrm{ab}$ & $25,58 \mathrm{a}$ \\
\hline $4,5\left(\mathrm{H}_{3}\right)$ & $23,33 \mathrm{bc}$ & $24,67 \mathrm{bc}$ & $25,67 \mathrm{ab}$ & $25,33 \mathrm{~b}$ & $24,75 \mathrm{~b}$ \\
\hline Rerata & $23,04 \mathrm{c}$ & $23,92 \mathrm{~b}$ & $24,46 \mathrm{ab}$ & $24,89 \mathrm{a}$ & \\
\hline
\end{tabular}

$\mathrm{KK}=2,88 \% \quad \mathrm{BNJ} \mathrm{HN}=2,11 \quad \mathrm{BNJ} \mathrm{H} \& \mathrm{~N}=0,77$

Angka-angka pada baris yang diikuti huruf kecil yg sama menunjukkan tidak berbeda nyata menurut uji lanjut Beda Nyata Jujur (BNJ) pada taraf 5\%.

Pada Tabel 7 menunjukkan bahwa secara interaksi pemberian Herbafarm dan Pupuk NPK Mutiara 16:16:16 memberikan pengaruh yang berbeda nyata terhadap berat biji kering pertanaman, dengan perlakuan terbaik pada pemberian herbafarm $3 \mathrm{cc} / \mathrm{l}$ air dan pupuk NPK Mutiara 21,6 g/plot dengan persentase polong berisi penuh mencapai 27,50 gram. Ini dikarenakan kemampuan herbafarm dalam meningkatkan sistem imunitas terhadap kondisi lingkungan yang kritis sehingga fotosintesis tanaman berlangsung optimal.

Setyoko dkk (2012), meningkatnya sistem imunitas tanaman dan sistem distribusi nutrient melalui pemberian herbafarm memungkinkan aplikasi pada dosis rendah sudah mampu memberikan pengaruh optimal terhadap hasil produksi tanaman budidaya.Dengan sistem imunitas yang tinggi tanaman memiliki daya tahan kuat terhadap kondisi lingkungan budidaya yang tidak ideal sekalipun.Begitu pula dengan adanya kemampuan dalam meningkatkan dalam sistem distribusi nutrient dari herbafarm mampu meningkatkan mobilitas nutrient sehingga dapat secara seimbang terdistribusikan keseluruh bagian tanaman.

MenurutAgustina (2011) dalam Wahyudi (2018) menyatakan bahwa proses pengisian biji pada tanaman sangat ditentukan oleh tingkat pemenuhan hara dan proses fotosintesis tanaman, unsur hara yang dibutuhkan tersebut akan saling berkaitan dalam meningkatkan proses fotosintesis tanaman, unsur hara tersebut diantaranya yaitu N, P, K, Ca dan Mg.

\section{Berat Kering 100 biji (gram)}

Dari hasil pengamatan bobot kering 100 biji setelah dilakukan analisis sidik ragam, memperlihatkan bahwa secara interaksi pemberian herbafarm dan pupuk NPK Mutiara 16:16:16 tidak berpengaruh nyata terhadap bobot kering 100 biji, namun secara utama memberikan pengaruh nyata. Rata-rata berat kering 100 biji dapat dilihat pada Tabel 7.

Pada Tabel 7 menunjukkan bahwa secara utama pemberian herbafarm memberikan pengaruh yang berbeda nyata terhadap berat 100 biji tanaman kacang hijau, dimana perlakuan terbaik pada pemberian pupuk cair Herbafarm $3 \mathrm{cc} / \mathrm{l}$ air $\left(\mathrm{H}_{2}\right)$ yaitu 5,99 gram. Perlakuan ini tidak bebeda nyata dengan perlakuan Herbafarm 4,5 cc/l air $\left(\mathrm{H}_{3}\right)$ yaitu 5,89 gram, tetapi berbeda nyata dengan perlakuan lainnya. Ini disebabkan kandungan hara pada herbafarm lebih optimal dalam pemenuhan kebutuhan hara tanaman, sehingga menghasilkan produksi yang lebih baik.

Pada Table 7. menunjukkan bahwa secara utama pemberian Pupuk NPK Mutiara $21,6 \mathrm{~g} /$ plot $\left(\mathrm{N}_{2}\right)$ dengan berat 100 biji mencapai 5,96 gram. Perlakuan ini tidak berbeda nyata 
dengan perlakuan $\mathrm{N}_{3}$ yaitu 5,90 gram, tetapi berbeda nyata dengan perlakuan lainnya. Ini dikarenakan pemberian pupuk NPK mampu memberikan tambahan unsur hara terutama unusur $\mathrm{K}$ yang sangat dibutuhkan dalam pertumbuhan dan perkembangan biji.

Tabel 7. Rata-rata berat kering 100 biji dengan pemberian herbafarm dan pupuk NPK Mutiara 16:16:16 (gram).

\begin{tabular}{lclllll}
\hline & Herbafarm & \multicolumn{4}{c}{ Pupuk NPK Mutiara 16:16:16 (g/plot) } & \\
\cline { 2 - 5 } & Cc/l air & $0\left(\mathrm{~N}_{0}\right)$ & $10,8\left(\mathrm{~N}_{1}\right)$ & $21,6\left(\mathrm{~N}_{2}\right)$ & $32,4\left(\mathrm{~N}_{3}\right)$ & Rerata \\
\hline $0\left(\mathrm{H}_{0}\right)$ & & 5,07 & 5,33 & 5,11 & 5,58 & $5,27 \mathrm{c}$ \\
$1,5\left(\mathrm{H}_{1}\right)$ & 5,18 & 5,33 & 5,96 & 5,61 & $5,52 \mathrm{~b}$ \\
$3,0\left(\mathrm{H}_{2}\right)$ & 5,49 & 5,73 & 6,40 & 6,33 & $5,99 \mathrm{a}$ \\
$4,5\left(\mathrm{H}_{3}\right)$ & 5,67 & 5,48 & 6,34 & 6,08 & $5,89 \mathrm{a}$ \\
\hline Rerata & $5,35 \mathrm{c}$ & $5,47 \mathrm{~b}$ & $5,96 \mathrm{a}$ & $5,90 \mathrm{a}$ & \\
\hline
\end{tabular}

$\mathrm{KK}=8,52 \% \quad$ BNJ H\&N $=0,78$

Angka-angka pada baris yang diikuti huruf kecil yg sama menunjukkan tidak berbeda nyata menurut uji lanjut Beda Nyata Jujur (BNJ) pada taraf $5 \%$.

Penggunaan pupuk anorganik memegang peranan penting untuk menambah kebutuhan unsur hara tanaman, terutama pada tanah-tanah miskin hara.Keunggulan sifat pupuk anorganik khususnya pada pupuk majemuk yaitu memiliki unsur hara dalam bentuk tersedia sehingga dapat langsung mengandung unsur hara utama yang dibutuhkan tanaman dan mengandung satu atau lebih unsur sekunder dan unsur mikro yang dapat dimanfaatkan tanaman saat setelah diaplikasikan (Hakim dkk, 2006).

\section{KESIMPULAN}

Dari hasil penelitian yang telah dilaksanakan dapat diambil kesimpulan bahwa:

1. Interaksi pemberian herbafarm dan pupuk NPK Mutiara 16:16:16 berpengaruh nyata terhadap kecepatan pengisian bahan kering, persentase polong bernas pertanaman, dan berat biji kering panen pertanaman. Perlakuan terbaik adalah pemberian herbafarm $3 \mathrm{cc} / \mathrm{l}$ air dan pupuk NPK Mutiara 16:16:16 dosis $21,6 \mathrm{~g} /$ plot.

2. Pengaruh utama herbafarm berpengaruh nyata terhadap tinggi tanaman, umur berbunga, kecepatan pengisian bahan kering, waktu pengisian efektif, persentase polong bernas pertanaman, berat biji kering panen pertanaman, dan berat 100 biji. Perlakuan terbaik pemberian herbafarm $3 \mathrm{cc} / 1$ air.

3. Pengaruh utama pupuk NPK Mutiara 16:16:16 berpengaruh nyata terhadap tinggi tanaman, kecepatan pengisian bahan kering, waktu pengisian efektif, persentase polong bernas pertanaman, berat biji kering panen pertanaman yaitu pada perlakuan terbaik pupuk NPK Mutiara 16:16:16 dosis 21,6 g/plot. Sedangkan umur berbunga dan berat 100 biji perlakuan terbaik pupuk NPK Mutiara 16:16:16 dosis 32,4 g/plot

\section{DAFTAR PUSTAKA}

Alfandi. 2015. Kajian pertumbuhan dan hasil tanaman kacang hijau (Vigna radiata $\mathrm{L}$.) akibat pemberian pupuk $\mathrm{P}$ dan inokulasi cendawan mikoriz arbuskula (CMA). Jurnal Agrijati Fakultas Pertanian Unswagati Cirebon. 28 (1) : 3

Amilia, Y. 2005. Penggunaan pupuk organik cair untuk mengurangi dosis penggunaan pupuk anorganik pada padi sawah (oryza sativa L.).Skripsi Departemen Agronomi dan Hortikultura Fakultas Pertanian Institusi Pertanian Bogor.

Anonimus. 2016. Katalog provinsi riau dalam angka 2016. Badan Pusat Statistik Provinsi Riau. Hal 285..2009. Analisis kandungan pupuk Bio organik herbafarm. PT Sidomuncul. Semarang.

Asrul N, Rover dan Mashadi. 2012. Uji beberapa varietas dan pemberian pupuk bio organik herbafarm terhadap pertumbuhan dan produksi jagung manis (Zea mays Saccharata. Sturt). Jurnal green swarnadwipa, 3:85-92

Bambang. 2007. Kacang hijau teknik budidaya dan analisis usaha tani. Aneka Ilmu. Semarang.

Buana, R. G. T. 2016. Pengaturan jarak tanam dan pengaruhnya terhadap perkembangan biji dari 4 varietas kacang hijau (Vigna 
radiata L.).Skripsi Universitas Islam Riau.Pekanbaru.

D, Petrus A. 2016. Pengaruh hormon indole acetic acid (IAA) terhadap perkembangan biji empat varietas kacang hijau (Vigna radiata L.).Skripsi Universitas Islam Riau.Pekanbaru.

Gunawan, Riki. 2016. Pengaruh pupuk TSP terhdap pertumbuhan dan produksi empat varietas kacang hijau (Vigna radiata $\mathrm{L}$.). Skripsi Universitas Islam Riau.Pekanbaru.

Hadisuwito, S. 2012. Membuat pupuk organik cair. Agromedia Pustaka. Jakarta.

Hanapi, M. 2014. Pemberian pupuk herbafarm dan ZPT ajib terhadap pertumbuhan dan produksi tanaman kacang kedelai (Glycine max. L). Skripsi Universitas Islam Riau. Pekanbaru.

Harianto, H., Abdul Fatah, dan Hery Sutejo. 2014. Pengaruh konsentrasi dan waktu pemberian limbah cair PKS terhadap pertumbuhan dan hasil tanaman kacang panjang (Vigna sinensis L). Jurnal Agrifor Fakultas Pertanian Universitas 17 Agustus 1945 Samarinda. 13 (1) : 41-48

Hasanudin. 2012. Pemberian liquid sludge kelapa sawit dan pupuk Sp-36 terhadap pertumbuhan tanaman kacang hijau (Vigna radiata L.). SkripsiUniversitas Islam Riau.Pekanbaru.

Heni. 2007. Kacang Hijau. Sejarah perkembangan kacang hijau.Pertumbuhan tanaman kacang hijau. Penebar Swadaya. Jakarta.

Hidayat, Y. 2010. Perkembangan bunga dan buah pada tanaman surian (Yoonasinesis roem). Jurnal Agrikultur 2 (1) 13-20

HS, Raja I. 2016 Intensitas penyiangan gulma dan pengaruhnya terhadap perkembangan biji dari 4 varietas kacang hijau (Vigna radiata L.).Skripsi Universitas Islam Riau.Pekanbaru.

Iswanda, E. 2018. Pengaruh pemberian pupuk NPK Mutiara 16:16:16 dan Mikroorganisme Lokal (MOL) Bonggol Pisang terhadap Pertumbuhan danProduksi Kacang Hijau (Vigna radiata L.). Skripsi Universitas Islam Riau.Pekanbaru.

Jumadi. 2015. Pengaruh pemberian pupuk herbafarm cair dan NPK organik terhadap pertumbuhan tanaman buncis
(Phaseolus vulgaris. L). Skripsi Universitas Islam Riau. Pekanbaru.

Kunah. 2006. Pupuk dan cara pemupukan. Terjemahan Ui Saleh. Bahtera. Jakarta.

Lakitan. 2007. Bercocok tanam kacangkacangan, kacang hijau. Penebar Swadaya. Jakarta.

Lingga dan Marsono. 2001. Petunjuk penggunaan pupuk. Penebar Swadaya. Jakarta.

Martono, Sigit dan Paulus. 2005. Pupuk akar, jenis dan aplikasi, Cet. IV. Penebar Swadaya. Jakarta.

Maulana, Prasetya, B dan Soemarno. 2013. Pengaruh kompos, pupuk kandang dan custom-bio terhadap sifat tanah pertumbuhan dan hasil tebu (Saccharum officinarum L) pada Fntisol di kebun Ngrangkah-Pawon Kediri. Jurnal Teknologi Hijau Indonesia Fakultas Pertanian Universitas Brawijaya Malang. 2 (1) : 45-53

Millatina, Halus S dan Agusni. 2016. Pengaruh penggunaan mikro organisme lokal limbah rumah tangga dan NPK terhadap pertumbuhan dan hasil tanaman kacang hijau (Vigna radiata L.). Jurnal Agrotropika Hayati Fakultas Pertanian Universitas Almuslimim. 3 (1) : 7

Musnawar, E. I. 2006. Pupuk organik cair dan padat:pembuatan dan aplikasi. Penebar Swadaya. Jakarta.

Purnamawati. 2007. Syarat tumbuh tanaman kacang hijau. Budidaya tanaman pangan.Litbang.deptan.go.id.www.puslitt an.bogor.net. Diakses pada tanggal 8 Mei 2017.

Purwono dan Hartono, R. 2005.Kacang hijau. Penebar Swadaya. Jakarta.

Purwono dan Purnamawati. 2007. Budidaya 8 jenis tanaman pangan unggul. Penebar Swadaya. Jakarta.

Rasyad.A, Yusmar M dan Yetti E. 2014. Perkembangan biji dan mutu benih beberapa genotif kedelai yang diberi pupuk P. Jurnal Agroteknologi Trop. 3 (1) : 6-11

Ratnasari. D., Bangun, K. M. Dan Damanik, M. I. R. 2015. Respon dua varietas kedelai (Glycine max L. Merrill) pada pemberian pupuk hayati dan NPK majemuk.Jurnal Online Agroteknologi Fakultas Pertanian 
Universitas Sumatera Utara. Medan. 3 (1) : 276-282.

Rusnadi, T., Candra, P. K dan Supriyanto, B. 2003.Pengaruh pemberian pupuk NPK Mutiara dan jarak tanam terhadap pertumbuhan dan hasil tanaman kacang hijau (Vigna radiata L.).Jurnal Budidaya Pertanian Fakultas Budidaya Pertanian Universitas mulawarman.Samarinda.

Samekto, R, MP,. 2006. Pupuk Herbafarm. PT Citra Aji Parama, Cet. Pertama. Yogyakarta.

Setyoko, Y. Sukaya dan Pardono.2012. Pengaruh Macam dan Dosis Pupuk Organik terhadap Pertumbuhan dan Hasil Tanaman Pare (Momordica charantia L.).Jurnal Sains dan Teknologi Indonesia 3 (5): 55-63.

Sinaga. 2012. Kandungan pupuk majemuk NPK. Yayasan Prosea Indonesia. Bogor.

Siswadi. 2006. Budidaya tanaman palawija. Citra Aji Parama. Yogyakarta.

Sotedjo, M. 2010. Pupuk dan cara pemupukan. Rineka Cipta. Jakarta

Sumarji. 2013. Laporan kegiatan penyuluhan teknik budidaya tanaman kacang hijau. Fakultas Pertanian Universitas Islam Kediri.Http://PascauniskaKediri.ac.id/filesPengabdian/Kacanghijau .pdf.Diunduh pada 8 Oktober 2017.

Syafrianto. 2015. Pemberian pupuk kandang ayam dan pupuk NPK mutiara 16:16:16 terhadap pertumbuhan dan produksi tanaman labu (Cucurbita pepo L). Skripsi Universitas Islam Riau.Pekanbaru.

Wahyudi, A. 2018.Pengaruh Pemberian Fly Ash danLeginterhadap Pertumbuhan dan Produksi Tanaman Kacang Hijau (Vigna radiata L.).Skripsi Universitas Islam Riau.Pekanbaru.

Wedari, Ngurensiti. 2012. Pupuk Bio Organik Herbafarm.http//www. Herbafarmnutriend.com/infoherbafarm.ht $\mathrm{ml}$.

Widyastuti. R, Nurul H. Listiana dan Widyantoro. 2018. Pengaruh pemberian pupuk organik cair herbafarm terhadap perkecambahan benih sambiloto. Jurnal online UNS. Vol $2: 1$. 
